January 1994

\title{
Current Concepts-Past Contributions
}

Cynthia L. Theiss, MD

Thomas Jefferson University Hospital

Follow this and additional works at: https://jdc.jefferson.edu/jeffjpsychiatry

Part of the Psychiatry Commons

Let us know how access to this document benefits you

\section{Recommended Citation}

Theiss, MD, Cynthia L. (1994) "Current Concepts-Past Contributions," Jefferson Journal of Psychiatry. Vol. 12 : Iss. 1 , Article 15.

DOI: https://doi.org/10.29046/JJP.012.1.013

Available at: https://jdc.jefferson.edu/jeffjpsychiatry/vol12/iss1/15

This Article is brought to you for free and open access by the Jefferson Digital Commons. The Jefferson Digital Commons is a service of Thomas Jefferson University's Center for Teaching and Learning (CTL). The Commons is a showcase for Jefferson books and journals, peer-reviewed scholarly publications, unique historical collections from the University archives, and teaching tools. The Jefferson Digital Commons allows researchers and interested readers anywhere in the world to learn about and keep up to date with Jefferson scholarship. This article has been accepted for inclusion in Jefferson Journal of Psychiatry by an authorized administrator of the Jefferson Digital Commons. For more information, please contact: JeffersonDigitalCommons@jefferson.edu. 


\title{
"Current Concepts-Past Contributions"
}

\author{
WOMEN BEYOND FREUD: NEW CONCEPTS OF FEMININE PSYCHOLOGY \\ Edited by Milton M. Berger, M.D., with chapters by Marianne Horney Eckardt \\ Carol Gilligan, Douglas H. Ingram, Helen Singer Kaplan, Harold I. Lief, Jean Baker \\ Miller, Silvia W. Olarte, Susan Quinn, and Mario Rendon \\ Brunner/Mazel, Inc., New York, 1994, 162 pages, $\$ 26.95$
}

\section{Cynthia L. Theiss, M.D.}

This newly published volume is a collection of papers and commentaries drawn from the November 1991 conference celebrating the 50th anniversary of the founding of the Karen Horney Psychoanalytic Center in New York City in 1941. The contributors are well-known in the field of feminine psychology and have many individual areas of expertise as well. It is difficult to do justice to each chapter and author in a short book review, and a full reading is wholeheartedly recommended. This finely edited book is a tribute to Karen Horney's contributions to psychoanalysis, as posited in the introduction by Dr. Milton Berger.

One of the remarkable things about the book is its format. There are excellent individual chapters, which are followed by commentary chapters. The open commentary, discussion and even disagreement found in these chapters are consistent with the ideals of Karen Horney. This remarkable woman was herself forced out of the psychoanalytic mainstream and stripped of her academic status due to challenging the "phallocentric theory of Freud, the primacy of masculine libido, and the relegation of women to a position of natural deviance" (p. 154). However, as her daughter, Marianne Horney Eckardt points out in the second chapter, Karen Horney's views were not born of the modern feminist movement, but rather of the post-World War I environment in Berlin, where her early influences and early career development were fostered.

The chapters in this book attempt to trace the development and influences of Karen Horney and to further extend and formulate the ideas and theories she put forth. Susan Quinn, author of A Mind of Her Own: The Life of Karen Horney (1978), renders a chapter on the early influences and family life that might have contributed to the independence and creative spirit of Karen Horney. She traces Horney's writings from the earliest adolescent diaries through the early papers and to her mature works.

Cynthia L. Theiss, M.D. is a fourth year resident at Thomas Jefferson University in Philadelphia. 
A very excellent chapter is contributed by Marianne Horney Eckardt, M.D., who describes the political and social milieu of her mother's time that gave significance and meaning to her work. Karen Horney's early training in turn of the century Berlin was influenced by Karl Kraus, Otto Gross and Ellen Key and other important writers and thinkers of the post-World War I state who struggled with issues of male and female, political patriarchy vs. matriarchy, monogamy, equality, sovereignty and morality. In this chapter Eckardt points out Horney's passionate idealism about self-realization and its necessity for true relationships and commitment.

Helen Singer Kaplan, M.D., Ph.D. and Harold I. Lief, M.D. tackle issues of male and female sexuality in their lively chapters. They explore whether the liberated woman causes male impotence, and other topics such as penis envy, vaginal transference theory, sexual inhibition, and anger and hostility in relationships. The expertise of these two authorities in the realm of human sexuality make this section of the book especially valuable.

Jean Baker Miller, M.D. explores connections, disconnections and violations in women's psychological development. She notes the relatedness of women's lives and the style of empathic "mutually enhancing relationships" common to women's communications. She extends the observations of Horney as to the importance of relational connections in women's lives, and demonstrates how women's styles tend to enhance mutual growth. She envisions a mission for women to bring those devalued styles to their full status in the public sector to bring about social change.

Carol Gilligan, Ph.D., gives a treatise on the Harvard Project which was a study and endeavor to try to understand the fall-off in performance and self-esteem of pre-teen and early teen girls. "Girls' doubling of voice and vision is a response to a psychologically untenable split between what girls know through experience and what is socially constructed as reality" (p. 110). She aptly describes the myriad of social messages and cultural values that make this a difficult process for young women. The cost of not being able to maintain one's own voice and experience is measured in the loss of psychological health for women, and in interpersonal and political repression.

The final discussion chapters by Silvia W. Olarte and Mario Rendon each elaborate on subjects of the preceding two chapters. They both point to the positive relational and political outcomes that could be effected if these ideas and ideals are brought to fullness. There is a sense of moving beyond the Freudian goal of fulfillment of genitality, to an ideal of self-knowledge that instructs self-creation, mutuality in relationships and the possibility for social change.

I feel fortunate to have had the opportunity to review this book. Karen Horney's work was not a part of my residency training. While I acknowledge the difficulty of covering the myriad of areas needed for psychiatric education, I feel the omission of Karen Horney, given her important historical place, speaks to the silencing of women to which Karen Horney, the American Association of University Women and the Harvard research programs refer. My experience, personal and professional, has been validated by what I have read in this book. I am indebted to a woman who was 
able to challenge Freud, suffer the political consequences, and yet write about her beliefs and ideas and be heard and vindicated by history. She was not silenced.

As Marianne Horney Eckhardt stated, "Setting her writings on feminine psychology amid the passions of the early 20th century does what history always does: it deepens understanding and connects her with her past, but also with the quests we pursue in living with our own past" (p. 29). To some degree, the history of psychoanalysis and its important figures are our common past. 